\title{
FIBRE AND INDUSTRIAL WASTE REINFORCED CONCRETE-A REVIEW
}

\author{
Ridha Nehvi \\ Department of Civil Engineering \\ Sharda University \\ Greater Noida -India
}

\begin{abstract}
Use of concrete as a structural material is limited to certain extent by deficiencies like brittleness, poor tensile strength and poor resistance to impact strength, fatigue, low ductility and low durability .Over 400 million tons of waste materials are being produced by various industries every year Use of fibers $\&$ industrial wastes to partly replace cementing material in concrete system not only will reduce the construction cost but incorporation in concrete will enhance the continuity and integrity of concrete thereby increasing long-term tensile strength, which is beneficial to the safety and durability of concrete structures. Reinforced concrete can be used as an economical building cementations material thus reducing the disposal and air pollution problems caused by the industry and will contribute to a very satisfactory outlet of these industrial by-products which were earlier considered as waste materials and dumped on huge quantities on barren lands causing pollution problems.
\end{abstract}

Key words- Fiber, industrial waste reinforced concrete

\section{INROUCTION}

Concrete is a composite material composed of aggregate bonded together with a fluid cement which hardens over time. In Portland cement concrete (and other hydraulic cement concretes), when the aggregate is mixed together with the dry cement and water, they form a fluid mass that is easily molded into shape. The cement reacts chemically with the water and other ingredients to form a hard matrix which binds all the materials together into a durable stone-like material that has many uses ( $\mathrm{Li}, 2011)$.Often, additives (such as pozzolans or superplasticizers ) are included in the mixture to improve the physical properties of the wet mix or the finished material. Most concrete is poured with reinforcing materials (such as rebar) embedded to provide tensile strength, yielding reinforced concrete.

Concrete is not normally designed to resist direct tension. Principal tensile stresses may also result from multi-axial states of stress. Concrete without any fibers will develop cracks due to plastic shrinkage, drying shrinkage and changes in volume of concrete. Normally cracking in concrete occurs when tensile strength exceeds its limiting value. Pure shear in concrete causes tension on diagonal planes, thus the value of direct tensile strength of concrete is useful in estimating the shear strength of beams with unreinforced webs, etc. Also, the flexural tensile strength of concrete is required for estimation of the moment at first crack required for the computation of deflections and crack widths in flexural members.

There are two ways to resist this low tensile strength - by using reinforcement or by prestressing. Reinforcement in the form of industrial wastes, fabric or profiled bar (typically steel but may be FRP) of differing gauge or size, or potentially specialist fibres depending on the application, is placed in areas where tensile stresses will occur under load, however pre-stressing in concrete is where an internal stress has been introduced through steel strand impart compression into the concrete.

Reinforced concrete is strong in tension and is able to absorb the stresses developing in the concrete so long as a good bond between the concrete and reinforcement or pre-stressing strand is maintained. Development of micro cracks in concrete causes elastic deformation of concrete. By limiting the stresses that the reinforcement has to deal with, the cracking in to concrete can be kept within acceptable limits. The addition of fibers in plain concrete will control the cracking due to shrinkage and also reduce the bleeding of water. Reinforced concrete (RC) is a composite material in which concrete's relatively low tensile strength and ductility are counteracted by the inclusion of reinforcement having higher tensile strength and/or ductility. Reinforced concrete may also be permanently stressed (in compression), so as to improve the behavior of the final structure under working loads.

Fibres may be classified as either natural or manmade, and the natural fibres are further divided into different groups. There is currently a great deal of interest in developing the technology for using 


\section{International Journal of Engineering Applied Sciences and Technology, 2019 Vol. 4, Issue 5, ISSN No. 2455-2143, Pages 223-230 \\ Published Online September 2019 in IJEAST (http://www.ijeast.com)}

natural fibre materials in cement composites. Natural fibres exist in reasonably large quantities all over the world and natural vegetable fibres are produced in most developing countries. Natural fibres have been used to reinforce inorganic materials for thousands of years. Examples include straw for bricks, mud and poles, plaster and reeds. During this century other fibres such as coconut, bamboo, wood cellulose fibres, wool or chips, blast fibres, leaf fibres, seed and fruits fibres have been used in cement-sand based products. The main reasons for the use of natural fibres are abundantly available and are comparatively cheap. Natural fibre composites are also claimed to offer environmental advantages such as reduced dependence on non-renewable energy/materials sources, lower pollutant emissions, lower greenhouse gas emissions, enhanced energy recovery and end of life biodegradability of components. These fibres increase the toughness of the material so that the product can withstand handling and a structural load. Concrete mixtures can be designed to provide a range of mechanical and durability properties to meet the design requirements of a structure.

\section{RECENT ADVANCES IN REINFORCED RESEARCH}

Research and development work in Fiber Reinforced Concrete (FRC) composites began in India in the early 1970 s and is still taking place to understand the applications of fibre concrete materials (Fordos, 1989).Fiber reinforced concrete was developed to overcome the problems associated with cement based materials such as low tensile strength, poor fracture toughness and brittleness of cementations composites. There are so many type of polymer fiber available as secondary construction materials, The Recron-3S fiber is one of them, and The Reliance Industry Limited (RIL) has launched Recron-3S. Recron-3s polymer fiber for mixing concrete and mortar for improving certain properties of the concrete and mortar. Fibers have special triangular shape for better anchoring with other ingredient of the mix. Recron-3S fiber is available in $6 \mathrm{~mm}$ and $12 \mathrm{~mm}$ length. Recron-3s is a polypropylene monofilament discrete, discontinuous short fiber that can be used in concrete to control and arrest cracks (Dharani et al. 2013).

Alhozaimy et al.(1996), Qian and Stroeven ( 2000), Kalifa et al. (2001), Song et al.( 2005), Kim et al.( 2008) and Pakravan et al .(2010) reported that fibre reinforced concrete (FRC) has been successfully used in construction for its excellent flexuraltensile strength, resistance to splitting, impact resistance and excellent impermeability and frost resistance. It is also an effective way to increase toughness, shock resistance and resistance to plastic shrinkage cracking of the mortar. Adeyemi (1998) studied suitability of coconut fibre as substitute for either fine or coarse aggregate in concrete production. It is examined that the coconut fibres were more suitable as low strength-giving lightweight aggregate when used to replace common coarse aggregate in concrete production. Coconut fibres are lighter than the conventional coarse aggregate so the resulting concrete will be lightweight. Therefore, it can be used as a good replacement of coarse aggregate to produce structural concrete in the construction industry.

Study by Olanipekun et al. (2006) has shown that coconut shell is suitable as substitute for conventional aggregates in the structural concrete production. The results indicated cost reduction of $30 \%$ for concrete produced from coconut shells. It was also expected to serve the purpose of encouraging housing developers in investing in house construction incorporating these low-cost materials. Gunasekaran and Kumar (2008) have investigated the possibilities of using coconut shell as aggregate in concrete. The findings indicated that water absorption of the coconut shell aggregate was high about $24 \%$ but the crushing value and impact value was comparable to that of other lightweight aggregates. It is concluded that crushed coconut shells are suitable when it is used as substitute for conventional aggregates in lightweight concrete production. The results of tests carried out by Al-Feel and Al-Saffar (2009) to study the effect of curing methods on the compressive, splitting, and flexural strength of selfcompacting concrete showed that water cured specimens gave the highest results of concrete compressive strength, splitting tensile strength, and flexural strength than specimens cured in air by about $11 \%, 10 \%$, and $11 \%$ respectively. The results also indicated that SCC gave high early concrete compressive strength.

Majid (2010) reported that coconut fibres have the highest toughness amongst natural fibres. The influence of $1 \%, 2 \%, 3 \%$ and $5 \%$ fibre contents by mass of cement and fibre lengths of 2.5, 5 and $7.5 \mathrm{~cm}$ revealed that Damping of CFRC beams increased while their fundamental frequency decreases with structural damage. CFRC with higher fibre content has a higher damping but lower dynamic and static modulus of elasticity. It was also found that CFRC with a fibre length of $5 \mathrm{~cm}$ and a fibre content of $5 \%$ had the best properties. Alida et al. (2011) reported the effect of natural fiber content on the physical and mechanical properties as well as fracture behavior of composite cement reinforced with coconut fiber. It was observed that the composite reinforced with $9 \mathrm{wt} \%$ of coconut fiber demonstrated 


\section{International Journal of Engineering Applied Sciences and Technology, 2019 Vol. 4, Issue 5, ISSN No. 2455-2143, Pages 223-230 \\ Published Online September 2019 in IJEAST (http://www.ijeast.com)}

the highest strength of modulus of rupture and compressive strength.

Increasing content of coconut fiber will increase the modulus of rupture and compressive strength of the composites up to a certain optimum composition. In this work, the optimum content of coconut fiber was 9 wt. \%. Further increase in coconut fiber content will decrease the mechanical properties due to less workability. Increasing in fiber content also increased the percentage of water absorption and moisture content. The fracture behavior of high strength composite consists of crack bridging and fiber push out that are responsible to resist crack propagation and improve the strength of the composite. Dash (2011) used Recron-3s fiber and silica fume for making concrete. The compressive strength and the flexural strength of the concrete specimens were determined. The optimum strength was obtained at $0.2 \%$ fiber content. Mechanical properties of coconut fibres reinforced polyester composites conducted by Mulinari et al. (2011) revealed a decrease in fatigue life of composites when applied greater tension, due to bonding interfacial, which was not adequate.Patodi and Kulkarni (2012) found that matrix having $0.3 \%$ of recron and $0.7 \%$ of steel fiber volume fraction was found. More balanced in terms of strength and post - peak ductility. Best resistance against impact and maximum toughness. For overall better performance. Advantages in improving concrete properties.

Sadiqul et al. (2012) reported that the high cost of conventional construction materials is a dominating factor affecting housing system around the world. The study including chopped coconut fibers

composites incorporating different volume percentage of fibres showed that the compressive strength of the concrete decreased as the fibres volume percentage of the coconut increased in the concrete mix. Experimental results also demonstrated that the coconut fibre concrete performed satisfactorily on the growth of cracks, crack widths compared with conventional concrete. Finally, it was concluded that the use of coconut fibre has great potential in the production of structural lightweight concrete especially in the construction of low-cost concrete structures. \& can enhance higher toughness. Pitorda et al. (2012) reported that Compressive strength is reduced when replacement of hypo sludge percentage increases when compare to traditional concrete. Replacement of cement with hypo sludge provides maximum compressive strength at $10 \%$ replacement but it is lesser than traditional concrete. Flexural strength of beam reduces when replacement of hypo sludge percentage increases when compare to traditional concrete. Zoran et al. (2012) concluded that Abrasive resistance of concrete is reduced with the increase of water/cement ratio from 0.5 to 0.7 which is reflected in the increase of the value of abrasion resistance rate. The addition of fibers increases tensile strength across the entire range of water/cement factors from 0.5 to 0.7 in respect to the benchmark concrete. The concretes with high compressive and tensile strength (at bending) have higher abrasive resistance, so these parameters may serve as indicators of the abrasive-erosive resistance of concrete. The polypropylene fibrillated fibers proved better in respect to the monofilament fibers in terms of abrasive- erosive resistance of concrete.

Bhosale and Kawade (2013) revealed that Ground Granulated Blast Furnace Slag act as cost reducing ingredient and also increase many mechanical properties of concrete. Mechanical properties of pozzolanic concrete using GGBFS show that this concrete gives better compressive strength and increases durability of concrete. Polypropylene fiber also increased the mechanical properties like compressive strength, flexural strength and split tensile strength of concrete. It was seen that the compressive strength and the tensile strength decreased however the flexural strength of the fibre reinforced concrete increased by $0.2 \%$.

Dharani et al. (2013) reported that the optimal replacement percentage of cement with hyposludge is found to be $30 \%$ when Recron 3 s fibers are not added. On addition of Recron 3 s fiber with cement matrix, the compressive strength and split tensile strength decrease with increase in fiber content, however the flexural strength increases with increase in fiber content. When hyposludge and Recron 3s fiber are added, the optimum dosage of Hyposludge is $20 \%$ and optimum Fiber content is $0.4 \%$. Usage of Recron $3 \mathrm{~s}$ fibers will reduce the segregation, cost of maintenance by reducing the micro cracks and permeability and hence the durability will increase.Praveen and Sharma (2013) suggested that addition of polypropylene fibre has a little effect on the compressive strength, but there was significant increase in the tensile strength with increase in fibre volume fraction. The present investigation shows an increase of $47 \%$ of split tensile strength and $50 \%$ of flexural strength. High percentage of fly ash (more than 50\%) could not be used to produce SCC when PPC was used, and $30 \%$ replacement of fly ash exhibited the highest compressive strength, splitting tensile strength and elastic modulus. It can be concluded from the literature that, the use of mineral admixtures reduces the material cost of the SCCs and also improves fresh and hardened properties of the concrete mix.

An investigation on using Coconut Fibre Ash (CFA) as a partial re-placement for cement in concrete production was carried by Okere et al.(2013). The slump test result shows that the 


\section{International Journal of Engineering Applied Sciences and Technology, 2019 Vol. 4, Issue 5, ISSN No. 2455-2143, Pages 223-230 \\ Published Online September 2019 in IJEAST (http://www.ijeast.com)}

workability of the concrete decreased as the CFA content increased. Results showed that the compressive strength of CFA concrete increased with curing age but decreased with increasing percent age of coconut fibre ash. Prasad et al. (2013) investigated the workability and flexural strength of cement concrete containing silica fume and polypropylene fibers. The experimental test results demonstrated that addition of polypropylene fibers at $0.4 \%$ volume fraction showed considerable gain of flexural strength of $4.95 \mathrm{MPa}$ and $7.32 \mathrm{MPa}$ at 7 and 28 days respectively. The behavior of concrete under flexural loads was found to be consistently improved compared with reference mix design. The results showed that the use of $10 \%$ silica fume combined with $0.40 \%$ fiber volume fraction results in optimum mixture design for applications from the standpoints of workability and flexural strength. Sharmila \& Thirugnanam (2013) indicated that the effect of adding hybrid fibres influence the behavior of beams by increasing the ductility characteristics by $80 \%$ and energy absorption characteristics by more than $160 \%$ Instead of adding single fibre, the combination of different types of fibres (Hybrid fibres) increases the energy absorption capacity substantially.

Balamurugan and Karthickraja (2014) noticed that the compressive strength increased up to $10 \%$ addition of hypo sludge and further increase in hypo sludge reduces the strengths gradually. If silica is added the strength will be considerably increased, because of lack of silica in hypo sludge, considerably this type of Concrete, will be used for road works effectively with less consumption of cement. Parbhane and Shinde (2014) investigated that the workability and tensile strength of concrete increased to some extent as the coir increased. Concrete produced by $1 \%, 2 \%, 3 \%, 4 \% \& 5 \%$ addition attained 28 days tensile strength of 2.68 , $2.90,3.11,3.25,2.33$ respectively. These results showed that Coir Fibre Concrete can be used in reinforced concrete construction. Its utilization is eco-friendly. Ramli et al. (2013) reported that marine structures have suffered from seawater attacks for decades. The experimental results prove that the compressive and flexural strengths of the structures improve up to $13 \%$ and $9 \%$, respectively, with the incorporation of coconut fibers. However, in terms of durability, the chloride penetration, intrinsic permeability, and carbonation depth increase with the increase in fiber content. The results signifies that the fibers play a role in restraining the development of cracks. In general, the deleterious effects brought about by aggressive environments can be suppressed with fiberreinforced concrete. However, the dosage of coconut fiber should be low, not exceeding $1.2 \%$ of the binder volume, due to the drawback of its natural degradation
Agrawal et al. (2014) reported that compressive strength of concrete increases with curing age but decrease with increase in quantity of coconut fibre whereas its tensile strength increases. Abtahi et al.(2014) shows that polypropylene fiber modified bituminous concrete samples exhibits superior performance compared to other fiber reinforced samples. Polypropylene fibers decreases penetration and ductility of modified bitumen while the softening point value is increased compared unmodified bitumen specimen. They also suggested that Polypropylene (PP) fibers are preferred due to their low-cost and good consistency with bituminous pavement. Studies on significance of fibres in enhancing strength and corrosion resistance of fly ash blended quarry dust concrete by Devi (2014) revealed that Quarry dust which is generally considered as a waste material can be used as an economical alternative to the river sand since it has become a meager construction material and also highly pricey. Fly ash, which is the residue from coal-fired power plants, when used as partial replacement of cement in concrete, results in reduction of cement consumption and $\mathrm{CO} 2$ production besides enhancing strength and durability properties. Deterioration of concrete structures due to rebar corrosion is a matter of significant concern since the cost of repairing and rehabilitation of these structures is very expensive. Fibres can be utilized to obtain a durable concrete with low shrinkage and improved strength properties. From the results it has been arrived that fly ash blended quarry dust concrete along with polypropylene fibre can be effectively and economically utilized in the construction industry. The utilization of quarry dust and fly ash as construction materials not only reduces the construction cost but also contribute to a very satisfactory outlet of these industrial by-products which were earlier considered

as waste materials and dumped on huge quantities on barren lands causing pollution problems. Incorporation of polypropylene fibres in fly ash blended quarry dust concrete enhances the continuity and integrity of concrete thereby increasing long-term tensile strength, which is beneficial to the safety and durability of concrete structures. Ealias et al. (2014) reported that coconut shell and coir fibres are the natural materials which is abundantly available in tropical regions. The addition of fly ash helps to increase the strength and workability of concrete. Addition of fly ash helped improving the strength of concrete with partial replacement of coarse aggregate with coir fibres and coconut shell. Gurunaathan et al. (2014) showed addition of polypropylene fibers, recron3s fibers into the fly ash and silica fume in different concrete mixes marginally improve the compressive strength at 28 days. The minimum 


\section{International Journal of Engineering Applied Sciences and Technology, 2019 Vol. 4, Issue 5, ISSN No. 2455-2143, Pages 223-230 \\ Published Online September 2019 in IJEAST (http://www.ijeast.com)}

percentage of fly ash and silica fume were added in concrete so that the performance of the concrete increases. There is an increase from $3 \%$ to $9 \%$ in split tensile strength for all fiber mixes when compared with that of control mix. The volume fraction of hybrid fiber concrete mix gives better strength values on par with control mix. Shreeshail et al. (2014) observed that the compressive strength of fibre reinforced concrete increased by $13 \%$ in comparison to the conventional concrete. The split tensile strength increased upto $29 \%$ in comparison to the conventional concrete. The flexural strength increased by $50 \%$ as compared to the conventional control mix.

Dharani (2015) indicated that $10 \%$ replacement of cement with Hypo sludge and 50\% replacement of fine aggregate with Copper slag show increase in compressive strength and flexural strength compared to other combinations. $10 \%$ replacement of cement with Hypo sludge and $40 \%$ replacement of fine aggregate with Copper slag show increase in split tensile strength compared to conventional mix. With increase in curing days $30 \%$ replacement of cement with hypo sludge shows decrease in split tensile strength when compared to other combinations. Nilesh and Harishkumar (2015) reported that the industrial waste materials were found to be performing better than normal concrete, in properties such as workability, durability, permeability and compressive strength. Utilization of these wastes in concrete will not only provide economy but also help in reducing disposal problems. Husain and Aggarwal (2015) revealed that addition of Recron $3 \mathrm{~S}$ fibre increases the CBR and UCS value of the silty soil. It was evident from the results that Recron $3 \mathrm{~S}$ fibre helped in improving soil subgrade strength of silty soil. CBR test results revealed that CBR value of untreated soil increased from $3.50 \%$ to $20.2 \%$ with addition of $0.15 \%$ Recron $3 \mathrm{~S}$ fibre. It was also observed that addition of further Recron $3 \mathrm{~S}$ fibre to the soil in the quantity of $0.30 \%, 0.45 \%$ and $0.60 \%$ of dry weight of soil very little further increased the CBR value. Patel et al.(2015) from their studies found that the using of Recron-3s in Pavement quality concrete will increase the compressive strength and flexural strength. It is also found that the minimum crack is occurring under heavy load and this will decrease the water permeability. Usage of Recron-3s fibers will reduce the cost of maintenance by reducing the micro cracks and permeability and hence the durability will increase. Desale and Sisode (2015) reported tha addition of fly ash and Recron $3 \mathrm{~s}$ fibers had beneficial effects on the mechanical properties of concrete. From the results it was seen that the flexural strength of concrete increased by a percentage of $36 \%$ after 28 days of curing.

Study on Influence of fibres in enhancing strength and corrosion resistance of fly ash blended quarry dust concrete by Devi (2015) revealed that quarry dust which is generally considered as a waste material can be used as an economical alternative to the river sand since it has become a meager construction material and also highly pricey. Fly ash, which is the residue from coal-fired power plants, when used as partial replacement of cement in concrete, results in reduction of cement consumption and $\mathrm{CO} 2$ production besides enhancing strength and durability properties. From the results it has been arrived that fly ash blended quarry dust concrete along with polypropylene fibre can be effectively and economically utilized in the construction industry. The addition of a low volume fraction of polypropolyne fibres inhibits microcracking, bleeding and increase cement hydration in fresh concrete, thereby reducing surface permeability and reduction in formation and growth of micro cracks in concrete. Hence, it offers low permeability which in turn contributes to better durability and corrosion resistance. Mahabir et al.(2015) studied effect of synthetic fibres on concrete with GGBFS replaced cement and reported that the Recron fibers to the extent of $0.2 \%$ fiber content maintain the satisfactory properties of concrete. However, the resistance to capillary action and porosity problems in concrete is improved considerably. Study revealed that the normal consistency increases with replacement of cement by pozzolanic material such as GGBFS. In case of normal concrete, part replacement of cement by GGBFS decreases the compressive strength. However, satisfactory results are obtained with $20 \%$ replacement. Hence it is decided to go for $20 \%$ replacement for preparation of concrete for further investigations. Addition of fibres decreases the compressive strength and split tensile strength, with phenomenal change after $0.2 \%$. Flexural strength of concrete increases with fibre addition upto $0.1 \%$ by weight after which they decrease. Similarly the capillary absorption parameter decreases with fibre content upto $0.1 \%$ after which the value of this parameter increases, while the porosity increases with fibre content, but significant being after $0.1-0.2 \%$. Considering the above observations, it is concluded that within the range of tests conducted, 20\% GGBFS replacement of Portland slag cement with $0.2 \%$ fiber addition with would improve the dampening or seeping action of water in concrete besides satisfying the other conventional criteria. Nandish et al. (2015) reported that use of fibers tends to enhance the split tensile strength of the fibre mixed concrete which has a higher value than that of the control mix. For $2.0 \% \mathrm{CF}$ and $0.4 \% \mathrm{PF}$ of fibre content, the tensile strength was found to be $11.76 \%$ higher than that of control mix. Sandeep and Ready (2015) reported $12 \%$ increase in compressive strength with addition of fly ash when compared to plane concrete. Study 


\section{International Journal of Engineering Applied Sciences and Technology, 2019 \\ Vol. 4, Issue 5, ISSN No. 2455-2143, Pages 223-230 \\ Published Online September 2019 in IJEAST (http://www.ijeast.com)}

confirms that there is a reduction in the cost to the extent of $5 \%$ with the $30 \%$ flyash replacement and addition of $0.25 \%$ Recron with a concurrent increase of $25 \%$ strength. The addition of only fly ash is reducing the cost by $15 \%$ but the incremental gain in strength is limited to about $10 \%$. Sandeep (2015) reported that both grades of concrete attained maximum value at $25-30 \%$ of fly ash replacement in the 28 days compressive test. Compressive strength gets increased by $12 \%$ with addition of flyash when compared to plain concrete.

Nehvi (2016) studied the effect of different percentage of fibres on compressive, tensile and flexural strength of concrete besides determination of the suitable percentage of coconut fibre and polypropylene fibre in concrete. Slump tests confirmed that the workability of coconut fibre as well as the recron $3 \mathrm{~s}$ fibre in the mixes goes on decreasing as the fibre content increases in the concrete mix. Higher concentrations of coconut fibres recorded negative effect on compressive strength. For tensile strength and flexural strength recron $3 \mathrm{~s}(0.3 \%)$ and coconut fibre $(3 \%)$ recorded beneficial effects in improving the average tensile strength and average flexural strength. However, recron $3 \mathrm{~s}$ recorded maximum values for average tensile strength and flexural strength to the extent of $3.4 \mathrm{MPa} \& 6.83 \mathrm{MPa}$, respectively compared to $3.14 \mathrm{MPa}$ average tensile strength and $6.43 \mathrm{MPa}$ average flexural strength achieved with $3 \%$ coconut fibre. Higher concentrations in both fibres exhibited detrimental impact.Study confirmed beneficial effect of $0.3 \%$ recron $3 \mathrm{~s}$ and $3 \%$ coconut fibre as reinforcement for improving compressive, tensile and flexural strength values of concrete.

\section{CONCLUSION}

The addition of fibre and industrial waste into concrete improves the compressive strength, tensile strength and flexural strength. Reinforced concrete improves concrete properties in terms of workability, durability, permeability and compressive strength.

\section{ACKNOWLEDGEMENT}

Author thankfully acknowledge the support rendered by Department of Civil Engineering, Sharda University for giving me intellectual freedom in my work, engaging me in new ideas and demanding a high quality of work

\section{REFRENCES}

1. Agrawal A R., Dhase S S., and Agrawal K S.( 2014). "Coconut Fibre in Concrete to Enhance its Strength and making Lightweight Concrete. International Journal of Engineering Research \& Technology (IJERT). 9(8) : 64-67.

2. Abthai S M., Esfandiarpour S., Kunt M., Hejazi, M S., Ebrahimi, M G.(2014). Hybrid reinforcement of Asphalt concrete mixtures using glass and polypropylene fibers. Journal of Engineered Fibers And Fabrics.

3. Adeyemi A Y.(1998). An investigation in to the suitability of coconut shells as aggregates in concrete production. J. Env. Desighn Manag. 1:17-26.

4. Alfeel G R., and Alsaffar N S.(2009). Properties of self compacting concrete at different curing condition and their comparison with properties of normal concrete. Al-Rafidian Eng .17(3):30-38.

5. Alhozaimy A M ., Soroushian P., and

6. Mirza F.(1996). Mechanical properties of polypropylene fibre reinforced concrete and the effects of pozzolanic materials.Cement Concrete Composites 18, pp 85-92.

7. Alida A., Shamsul B., Mazlee M N., and Kmarudin H.(2011). Composite cement reinforced coconut fibre: physical and mechanical properties and fracture behavior. Australian Journal of Basic And Applied Sciences. 5(7): 1228-1240.

8. Balamurugan R., and Karthickraj

9. R.(2014). An Experimental Investigation of Partial Replacement of Cement by Industrial Waste (Hypo Sludge), ISSN: 2248-9622, 4(4) (Version 1), pp.430-435

10. Bhosale P A., and Kawade U. R. (2013).Effect of recron 3s fibres on GGBS replaced cement concrete. International Journal of Science and Research, Index Copernicus: 4.438.

11. Dash A K., Mahabir P., and Kishore C B.(2011). "Effect of Silica Fume on Engineering Properties of Fiber Reinforced Concrete" in Modern Methods and Advances In Structural Engineering and Construction. 1-7.

12. Desale S V., and Sisode B.(2015). "Use of industrial waste and recron $3 \mathrm{~s}$ fibre to improve the mechanical properties of concrete. Indian Journal of Research. IV.ISSN No: 2250-1991.

13. Devi M.(2014). Significnce of fibers in enhancing strength and corrosion resistance of ash blended quarry dust 


\section{International Journal of Engineering Applied Sciences and Technology, 2019 \\ Vol. 4, Issue 5, ISSN No. 2455-2143, Pages 223-230 \\ Published Online September 2019 in IJEAST (http://www.ijeast.com)}

concrete. International Conference on Biological Civil and Environmental Engineering.

14. Devi M.(2015). Influence of fibres in enhancing strength and corrosion resistance of fly ash blended quarry dust concrete. International Journal of Civil and Structural Engineering.5( 3):206-215.

15. Dharani. N., Ashwini A., Pavitha G., and Prince A G.(2013). Experimental investigation on mechanical properties of recron $3 \mathrm{~s}$ fiber reinforced hyposludge concrete. International Journal of Civil Engineering and Technology (IJCIET).4(1): pp. 182-189.

16. Dharani N; Prince Arulraj G and Goutham J.( 2015, Study on Mechanical Properties of Concrete with Industrial Wastes, ISSN: 2321-7308, 04(03), pp. 447 - 453.

17. Ealias., Anju M., Rajeena, A P.,and Sivadutt S., Life john., and Anju P.(2014). IOSR Journal of Mechanical and Civil Engineering (IOSR-JMCE). 11(3): PP 1624.

18. Fordos Z.(1989). Natural or modified cellulose fibers as reinforcement concrete in cement composits. In Concrete Technology.Des.5:173-207.

19. Gunasekaran K., and Kumar P S.(2008). Light weight concrete using coconut shells as aggregate. Proceedings of International Conference on Advances In Concrete And Construction.7-8 Feb, Hyderabad.

20. Gurunaathan K., Seenibasan G., and Thirugnanam G S.(2014)..Experimental study on strength and durability properties of fiber reinforced concrete. Proceedings of The Int Conference on Advances In Civil, Structure and Mechanical Engineering.

21. Pitroda J., Zala L B., and Umrigar F S.(2012). Experimental Investigations on Partial Replacement of Cement with Fly Ash in Design Mix Concrete, ISSN 09763945, 3(4), pp.126129

22. Kalifa P., Chene, G., and Galle C.(2001). High-temperature behaviour of HPC with polypropylene fibres: From spalling to microstructure. Cement Concrete Research 31 pp :1487-1499.

23. Kim D J., Naaman A E., and El-Tawil, S. (2008). Comparative flexural behavior of four fibre reinforced cementitious composites. Cement Concrete Composites 30, pp :917-928.

24. Mahabir P., Chandra B K., and Kumar D A. (2015). Effect of Synthetic Fibres on Concrete with GGBFS Replaced Cement .Indian Journal of Research.
25. Majid A. (2010). Coconut fiber-a versatile material and its applications in engineering. Second International Conference on Sustainable Construction Materials and Technologies. University of Wisconsin.

26. Husain M N., and Aggarwal P.(2014). "Application of recron 3s fiber in improving silty subgrade behavior IOSR Journal Of Mechanical And Civil Engineering (IOSR-JMCE).12(2). e-ISSN: 2278-1684, p-ISSN:2320-334X,"

27. Mulinari D R., Baptista,C A R., Souza J V C and Voorwald H J C.(2011).Mechanical properties of coconut fibres reinforced polyester composites. Procedia Eng.10:2074-2079.

28. Nandish S C., Ajith, B. T., and Chandrashekara, A.(2015).Impact of coconut fibre and polypropylene fibre (recron 3s) on concrete mix including admixture. International Journal of Engineering Research \& Technology (IJERT).4(6): ISSN: 2278-0181.

29. Nilesh V K and Harishkumar V R,(2015). Utilization of Various Waste Materials in Concrete a Literature Review, International Journal of Engineering Research \& Technology (IJERT), ISSN: 2278 - 0181, Vol. 4, Issue 04, pp. 1122 1126

30. Olanipekun E A., Olusola K O., and Ata O.(2006).A comparative study of concrete properties using coconut shell and palm kernel shell as coarse aggregates. Building and Environment..41(3):297-301

31. Okere.,Chineye., and Elizabeth. (2013). Strength properties of coconut fibre ash concrete". Journal of Research in Architecture and Civil Engineering (ISTPJRAC).

32. Pakravan H R., Jamshidi M., and Latifi M. (2010). Performance of fibres embedded in acementitious matrix. J Appl Polym Sci 116: 1247-1253.

33. Patodi S C., and Kulkarni C V. (2012). Performance Evaluation of Hybrid Fiber Reinforced Concrete Matrix, International Journal of Engineering Research and Applications, ISSN: 2248-9622, 2(5), pp:1856-1863

34. Prasad, M., Rajive C.,and Grover R.(2013).A comparative study of polypropiline fiber reinforced silca fume concrete with plane cement concrete. International $\mathrm{Jr}$ of Engineering Research and Science \& Technology.12(4):127-136. 


\section{International Journal of Engineering Applied Sciences and Technology, 2019 \\ Vol. 4, Issue 5, ISSN No. 2455-2143, Pages 223-230 \\ Published Online September 2019 in IJEAST (http://www.ijeast.com)}

35. Praveen and Sharma A.(2013).“Structural Behavior of FibrousConcrete Using Polypropylene Fibers", International Jornal for Research in Applied Sciences and Engineering Technology..3(3) pp1279-1282,

36. Parbhane D M., and Shinde S.(2014)."Strength Properties Of Coir Fibre Concrete", International Journal Of Civil Engineering and Technology (IJCIET Volume 5, Issue 2, pp. 20-24

37. Qian C X., and Stroeven P.(2000).Development of hybrid polypropylene- steel fibrereinforced concrete. Cement Concrete Research, 30, pp 63-69.

38. Ramli M., Wai H K., and Abas, N F.(2013). Strength and durability of coconut fibre reinforced concrete in aggressive environments. Journal of Construction and building materials. 38 .

39. Nehvi R.(2016). Impact of polypropylene fibre and natural fibre on the strength of concrete.M.Tech Dissertation .Sharda University Greater Noida

40. Sadiqul H N., Sobuz H R., Sayed M. S., and Islam.M, S.(2012). " The use of coconut fibre in the production of structural lightweight concrete. Journal of applied sciences. 12: 831-839

41. Sandeep T. (2015).Recron Medium Strength Fiber Reinforced Concrete.International Journl in IT and Engineering.ISSN:2321-1776,03(04),pp 131-134

42. Sandeep T., and Reddy M.(2015). Recron medium strength fibre reinforced concrete International journal in IT and engineering..03(04): issue-04, 2321-1776.

43. Sharmila S., and Thirugnanam G S.(2013). Behavior of reinforced concrete flexural member with hybrid fibre under cyclic loading, International Journal of Science and Technology, ISSN 2278-3687, 2(4), pp. $725-734$.

44. Shreeshail B H., Jaydeep C., Dhanraj, P., and Kulkarni A.(2014). Effects of coconut fibres on the properties of concrete". International journal of research in engineering and technology.

45. Song P.S., Hwang S., and Sheu B.C.( 2005). Strength properties of nylon- and Polypropylene -fibre-reinforced concretes. Cement Concrete Research, 35, pp: 15461550.

46. Zongjin L (2001)... Advanced concrete technology.ISBN:978-0-4700-43743-8.

47. Zoran G J., Gordana A., Toplicic C., Nenad R S and Iva D M. (2012). Abrasion resistance of concrete micro-reinforced with polypropylene fibers, Construction and Building Materials, 27(1), pp. 305312 . 